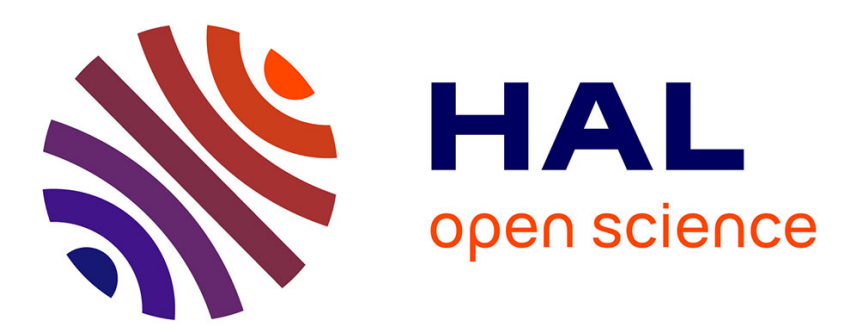

\title{
Effect on Comprehension of Preposed versus Postposed Adverbial Phrases
}

Saveria Colonna, Michel Charolles, Laure Sarda, Joël Pynte

\section{To cite this version:}

Saveria Colonna, Michel Charolles, Laure Sarda, Joël Pynte. Effect on Comprehension of Preposed versus Postposed Adverbial Phrases. Journal of Psycholinguistic Research, 2014, 43 (6), pp.771-790. 10.1007/s10936-013-9279-x . hal-00908696

\section{HAL Id: hal-00908696 https://hal.science/hal-00908696}

Submitted on 27 Nov 2013

HAL is a multi-disciplinary open access archive for the deposit and dissemination of scientific research documents, whether they are published or not. The documents may come from teaching and research institutions in France or abroad, or from public or private research centers.
L'archive ouverte pluridisciplinaire HAL, est destinée au dépôt et à la diffusion de documents scientifiques de niveau recherche, publiés ou non, émanant des établissements d'enseignement et de recherche français ou étrangers, des laboratoires publics ou privés. 


\title{
Title: EFFECT ON COMPREHENSION OF PREPOSED VS. POSTPOSED
}

\section{ADVERBIAL PHRASES}

Saveria Colonna ${ }^{1}$, Michel Charolles ${ }^{2}$, Laure Sarda $^{2} \&$ Joël Pynte

${ }^{1}$ University of Paris 8

UMR7023 Structures formelles du langage

59-61 rue Pouchet

75849 Paris cedex 17

France

${ }^{2}$ University of Paris 3

UMR 8094 LATTICE CNRS-ENS \& Université Paris 3

Ecole Normale Supérieure

1 rue Maurice Arnoux

92120 Montrouge

France

Key words: text comprehension, cohesion, adverbials, space.

\begin{abstract}
A challenge for psycholinguistics is to describe how linguistic cues influence the construction of the coherent mental representation resulting from the comprehension of a text. In this paper, we will focus on one of these linguistic devices: the sentence-initial positioning of spatial adverbials as In the park. Three self-paced reading experiments were conducted to test the 'Discourse Framing Hypothesis' according to which preposed adverbials can be seen as frame builders announcing that incoming contents satisfy a same informational criterion
\end{abstract}


specified by the adverbial. Our results indicated that spatial adverbials do not play the same role when they are in sentence-initial and in sentence-final position. These results are discussed in the framework of the Zwaan's Event Indexing Model. 


\section{INTRODUCTION}

Text comprehension involves the construction of a mental representation of the situation denoted by each sentence of the text. This representation, that has been called mental model (Johnson-Laird, 1983) or situation model (van Dijk \& Kintsch, 1983), evolves as the reader encounters new sentences. To construct and update this representation, readers have to combine linguistic cues of the text with their knowledge about previously experienced situations. It is widely admitted that a text can be seen as a set of processing instructions on how to construct a mental representation of the described situations (among others, Gernsbacher, 1990; Givon, 1995; Kintsch, 1992; Graesser, Singer \& Trabasso, 1994, Graesser, Millis, \& Zwaan, 1997; Zwaan \& Radvansky, 1998). However, many studies on text comprehension have neglected the role of some surface linguistic cues in the construction of this mental representation. In the present paper, we pay specific attention to some linguistic devices, namely to preposed spatial adverbial phrases that can help the reader to better grasp the coherence of the texts. We first present linguistic studies advocating the idea that preposed adverbials, unlike inserted or postponed ones, play a specific role in the organization of textual information. After recalling that the effect of the position of spatial adverbials on understanding has never been tested experimentally, we report three self-paced reading experiments designed to test this effect.

\section{Preposed adverbials as cohesive markers}

In linguistic studies, it is commonly admitted that the well-formedness of a text depends on its coherence and that this coherence can be either explicit (signalled by linguistic cohesion markers) or implicit. In recent years, many authors have proposed taxonomies of coherence 
relations in formal semantics and in computational linguistics (cf. Hobbs, 1990; Mann \& Thompson's Rhetorical Structure Theory, 1986, 1988; Kehler, 2002; Asher \& Lascarides's Segmented Discourse Representation Theory, 2003) and also in psycholinguistics (Knott \& Sanders, 1998). Although different in several respects, these taxonomies share the view that there are only two types of coherence relations: 'referential coherence', specifically expressed by anaphora, and 'relational coherence' expressed by connectives (Sanders \& Spooren, 2001). Apart from this position, it has been claimed (Charolles \& Prévost, 2003; Charolles \& PéryWoodley, 2005; Vigier \& Terran, 2005) that there is a third category of coherence relations named indexation relations, characterized by the forward-labelling properties of preposed adverbials. These relations play an important role in the organization of textual information. This role is illustrated in in text (1) (summary of a film excerpt from a TV magazine) which includes two preposed spatial adverbials (in bold), namely two spatial prepositional phrases (PPs).

(1) A New-York, Rabbi Jacob et son compagnon prennent l'avion pour Paris afin d'assister à une communion.(S1) En France, M. Pivert se hâte pour arriver à temps au mariage de sa fille.(S2) Enfin, deux tueurs vont enlever Slimane, chef révolutionnaire d'un pays arabe.(S3) Divers incidents font que Pivert et Slimane se substituent à Rabbi Jacob... (S4) (Les aventures de Rabbi Jacob)

In New York, Rabbi Jacob and his companion take the plane to Paris to attend a

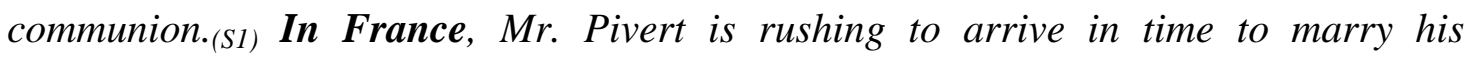

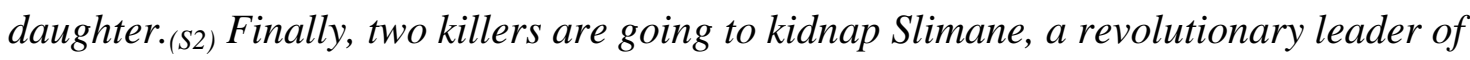
an Arabic country.(S3) Diverse incidents lead Pivert and Slimane to replace Rabbi $\operatorname{Jacob} \ldots(S 4)$

In excerpt (1), the two preposed adverbial prepositional phrases (PPs) in New York and in France localize the situations s1 and s2 denoted by the first two sentences S1 and S2. These 
adverbials introduce the spatial setting in which these situations take place; they open two spatial frames which evolve as the text goes on. The frame opened by in New York is closed by the new frame opened by in France and, because this second frame is not closed by a new spatial indication, it tends to extend its domain to the situation s3 and s4 denoted by S3 and S4. The organizational structure of (1) emerging at the end of the text can be schematized as in Figure (1).

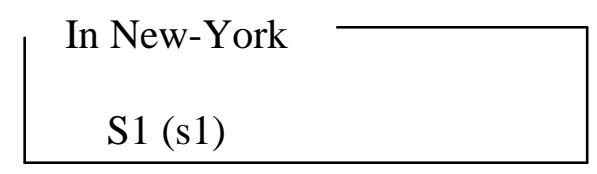

In France,

S2 (s2) S3 (s3) S4 (s4)

Figure 1. Organizational structure of text (1).

The three sentences belonging to the spatial frame introduced by in France are linked by the fact that they contrast with s1, which occurs in New York. The two PPs in New York and in France function like forward labelling markers and open a frame (a sort of "file" collecting ongoing information), which can integrate an indefinite set of incoming sentences. This integrative capacity is tied to the fact that the spatial adverbials appear at the beginning of their host sentences, and one of the main claims of the 'framing hypothesis', as we will see, is that the initial position itself encodes a specific organizational structure.

Preposed adverbial PPs have specific properties that provide them with an organizational capacity. They prevent any attachment to an intra-sentential component as can be seen in (1') by placing in New York at the end of the first sentence.

(1') Rabbi Jacob and his companion take the plane to Paris to attend a communion (,) in New York.(SI) In France, ...

In (1'), the PP in New York would be understood as an argument of the infinitive verb (to attend) and the entire sentence would require imagining a situation s1' in which Rabbi Jacob 
and his companion would have taken a plane making a stopover in Paris to reach New York, situation completely different from s1. The initial position of in France in (1) also avoids any ambiguities in the interpretation of S2, contrary to (1") where in France appears at the end of the sentence.

(1") In New York, Rabbi Jacob and his companion take the plane to Paris to attend a

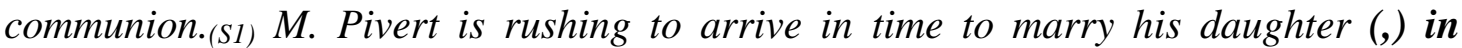
France. $_{(\text {S2) }}$ Finally ...

In the original example (1), the preposed position of in France prevents the readers from interpreting S2 in the scope of the first adverbial in New York and thus avoids a garden-path which would require reinterpreting S2 in the scope of in France. The two preposed adverbials which are by definition non argumental constituents (i.e. syntactic adjuncts) both contribute to the ideational content of their host sentence and assume organizing functions at the textual level $^{1}$ (Halliday, 2004). This discourse function is due to the fact that they have an extrasentential indexing role, contrary to inserted or postposed adverbials. The organizing role of preposed adverbials, first noticed by Thomspon (1985) has been strongly defended by many linguists both in English (Thompson \& Longacre, 1985; Quirk, Greenbaum, Leech \& Svartvik, 1985; Lowe, 1987; Downing, 1991; Virtanen, 1992; Goutsos, 1996; Hasselgård, 1996, 2004; Prideaux \& Hogan, 1993) and in French (Charolles, 2003; Charolles \& Vigier, 2005; Charolles, 2005; Sarda, 2005; Ho-Dac, 2007; Ho-Dac \& Péry-Woodley, 2009).

Crompton (2006) defends the opposite assumption. He claims that postposed adverbials can extend their scope on following sentences to the same extent as, if not more than, preposed adverbials do. Nevertheless, the English data of Crompton's corpus study are too limited to support his conclusion. His data included 217 prepositional and propositional adverbials of

\footnotetext{
${ }^{1}$ According to Halliday (2004), text has been interpreted as a three-level semiotic system "where the semantic unit, the text, unified through cohesive patterns, is the locus of choice in ideational, textual and interpersonal meaning" (p. 327). Ideational meaning concerns the message content, textual meaning concerns message structuring and interpersonal meaning concerns the adaptation of the message to a specific receiver.
} 
different semantic categories (spatial, temporal, conditional...) with very few samples of preposed uses for each category. Moreover, Crompton's corpus is composed of argumentative texts, which seem (i) too short (around 500 words) to be exploited with regard to the organizational capacity of preposed adverbials, and (ii) more interesting for a study of connectives.

Many results contradict Crompton's assumptions. For instance, Charolles' study (2006) on the French uses of the temporal adverbial un jour (one day), has shown that only preposed un jour / one day have a textual scope whereas inserted and postposed ones have a simple interpretative temporal span resulting from Grice's (1975) and Sperber et Wilson's (1986) relevance principle. Other corpus linguistic studies on French sentence beginnings (Ho Dac, 2007) such as temporal adverbials (Terran, 2002; Le Draoulec \& Péry-Woodley, 2003, 2005; Ho Dac \& Péry-Woodley, 2009; Piérard \& Bestgen, 2006), mediative adverbials like selon X / according to $X$ (Schrepefer-André, 2006) or domain adverbials like en chimie / in chemistry, en Tagalog / in Tagalog (Vigier, 2004, 2005) confirm the idea that, in French and probably in other languages (Lundquist, 2009; Sarda \& Carter-Thomas, 2009), preposed adverbials do contribute to the segmentation and cohesion of discourse.

All these linguistic studies suggest that preposed adverbials function as cues that the reader (or listener) keeps in mind for the processing of incoming information until another cue signals the end of their scope. Such a claim requires psycholinguistic investigations. In this paper, we present experimental data on the influence of the position of spatial adverbials (sentence-initial versus sentence-final) on reader's representations. To our knowledge, studies paying specific attention to this type of linguistic cues only deal with temporal markers. Bestgen and Vonk (2000), following Costermans and Bestgen (1991) and Bestgen and Costermans (1994), report a series of self-paced reading experiments in which participants had to read narratives referring to common human activities. A target sentence was preceded 
either by highly congruent sentences ("topic continuous" condition) or by weakly congruent sentences ("topic shift" condition). As expected, target sentences were read slower in the "topic shift" condition than in the "topic continuous" condition. However, this difference disappeared when a temporal adverbial such as vers onze heures / around eleven o'clock was inserted at the beginning of the target sentence, but not at its end. Bestgen and Vonk interpreted these results as demonstrating that "readers try to relate the new information by default to the preceding information" and that preposed temporal adverbials function as segmentation markers which "seem to direct the readers to bypass this step and to immediately start a new partition in their discourse representation" (p. 9). A third experiment showed that only preposed temporal adverbials as around eleven o'clock produce this effect, as opposed to what they call 'sentence adverbials' like as usual which do not produce this effect. In a fourth experiment, the target sentence was presented in two parts: the first part presented the temporal or the adverbial PPs, and the second part presented the rest of the target sentence. The results confirmed that, in the topic discontinuous condition, only temporal adverbial PPs reduce the processing of the second part of the sentence while they were read (in themselves) slower than the 'sentence adverbials'. According to Bestgen and Vonk, the reading of the temporal adverbials produces an increase in processing time because readers have to set up a new time interval. But this processing cost is offset by a facilitation of the processing required for a topic discontinuous sentence (compared to a topic continuous sentence). All results allow authors to conclude that temporal adverbials at the beginning of a sentence function as segmentation markers.

In the experiments presented below, we focused on the effect of spatial adverbial positioning on comprehension. In their experiments, Bestgen and Vonk were concerned by the segmentation function of temporal adverbials. From a slightly different viewpoint, we 
assessed the cohesive and organizational role of spatial adverbials to shed light on their framing capacity. This aspect had not yet been examined in experimental works. In order to fill this gap, we planned experiments in which we manipulated the position of spatial adverbials which could appear either at the beginning or at the end of the sentence. Participants had to read short narratives as in (2a-b) where the event mentioned in one of three target sentences (S7) was compatible with only one of the three locations previously introduced. The first space (where is the character) was introduced by a PP in an argument position (dans un hotel / in a hotel, dans sa chambre / in her room, de la fenêtre / to the window) whereas the two following spaces (dans le parc / in the park, devant la reception / in front of the entrance) were introduced by a non argumental (i.e. adverbial) spatial PP either in sentence-initial as in (2a) or in sentence-final positions as in (2b).

(2a) Marie logeait dans un hôtel.(S0) Elle monta dans sa chambre (s1) et s'approcha de la fenêtre.(S2) Dans le parc, des jardiniers s'activaient.(S3) Des oiseaux chantaient.(S4) Devant la réception, un portier faisait les cent pas.(S5) Une voiture attendait.(S6)

(Target) Le lit n'était pas fait.(S7)/ Les allées étaient bien ratissées.(S7)/ Le perron venait d'être lessivé.(S7)

Le printemps approchait.(S8)

Mary was staying in a hotel.(SO) $_{\text {She went up to her room }}^{(\mathrm{SI})}$ and walked over to the

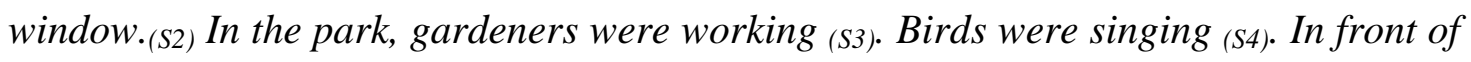
the entrance, the porter was walking up and down the street.(S5) A car was waiting.(S6)

(Target) The bed was not made.(S7) The lanes were well raked.(S7) The front steps had just been washed.(S7)

Spring was coming.(S8) 
(2b) Marie logeait dans un hôtel.(S0) Elle monta dans sa chambre (s1) et s'approcha de la fenêtre.(S2) Des jardiniers s'activaient dans le parc.(S3) Des oiseaux chantaient.(S4) Un portier faisait les cent pas devant la réception.(S5) Une voiture attendait.(S6)

(Target) Le lit n'était pas fait.(S7)/ Les allées étaient bien ratissées.(S7)/ Le perron venait d'être lessivé.(S7)

Le printemps approchait.(s8)

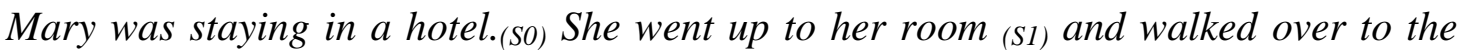

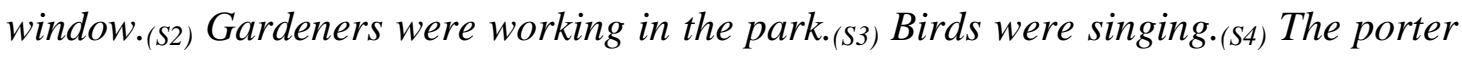
was walking up and down the street in front of the entrance.(S5) A car was waiting.(S6)

(Target) The bed was not made.(S7) The lanes were well raked.(S7) The front steps had just been washed.(S7)

Spring was coming.(S8)

Our experiments were designed to test the general hypothesis that the position of spatial adverbials (sentence-initial vs. sentence-final) affects the on-line processing of a text. More precisely, when the spatial adverbial phrases were in a potential framing position as in (2a), we expected that the latest space introduced by a spatial adverbial (in front of the entrance in the sample text in 2) was the most accessible because it opened a frame that should be still active when readers encounter the target sentence. This hypothesis is based on the right frontier attachment constraint, which is well known in computational linguistics (from Polanyi \& Scha, 1984 to Asher \& Lascarides, 2003) and in psycholinguistics literature as the late closure strategy (Kimball, 1973; Frazier \& Fodor, 1978). The right frontier constraint predicts that the components of a sub-structure are no longer available, or at least less accessible, once this sub-structure has been closed. This general principle applies to all structuring units from sentence to discourse. Asher (2005) notes that, in a text as (3), it is very difficult to refer back to the salmon with a pronoun because (we simplify) the sub-semantic 
discourse representation linking the segment he ate salmon to the segment he devoured cheese is closed by the segment he won a dancing competition.

(3) John had a great evening last night. He had a great meal. He ate salmon. He devoured lots of cheese. He then won a dancing competition. \#It/\#the salmon was a beautiful pink.

However, Asher (2005) and Asher, Prévost et Vieu (2007), following Vieu et Prévost (2004), note that, in some contexts, the use of an associative definite noun phrases (NP) ${ }^{2}$ is possible as in (4) where the pickpocket is unproblematic, contrary to the third person pronoun.

(4) This morning, in the subway, I almost got robbed. At some point, I noticed that a man was pulling at my purse. I just froze. I couldn't say a word. Suddenly, a woman screamed. The pickpocket / \# he let go of my purse and ran away.

According to the right frontier constraint, we purposely used definite associative NP in the target sentence to make sure that, in all conditions, all spaces were possibly accessible. We made further assumptions that these NPs would be easier to understand when their referents were associated with a spatial frame still active than with a spatial frame which had been closed and was no longer active. Thus, the space introduced by the first preposed spatial adverbial (in the park in 2) should be less accessible because the second one closes it. Also, in the postposed condition ( $2 \mathrm{~b})$, it would be possible for the last space introduced to be the most accessible because it is the most recent space. In the preposed condition (2a), the last space introduced should be more accessible compared to the first preposed one due to the cumulative effect of recency and framing.

\section{EXPERIMENTS 1A AND 1B}

\footnotetext{
${ }^{2}$ On associative or "inferable" definite NPs, cf. Charolles and Kleiber (1999) and Kleiber (2001).
} 


\section{Experiment 1A}

In this experiment, the participants read narratives as (2a-b) in a sentence-by-sentence selfpaced manner, with sentence reading time used as the dependent variable. In particular, reading times for the target sentence would inform us about which space was the most accessible between the three spaces previously introduced (respectively called the Origin Space, Space 1 and Space 2). As indicated earlier, we do not expect the same processing time on the target sentence in function of the space it evoked and of the position of the adverbial phrases (postposed vs. preposed). In the postposed condition, we predicted a recency effect i.e. the reading time on the target sentence should be the shortest when it evoked the latest space introduced (namely Space 2), and it should be shorter when it evoked the first space introduced by an adverbial (Space 1) than when it evoked the Origin Space (introduced by an argument PP). In the preposed condition, we expected that Space 1 should be less accessible because Space 2 closed it. We did not expect any difference when the target sentence evoked the Origin Space and when it evoked Space 2. The expected difference in the processing of the target sentence as a function of the position of the spatial adverbial should result in a statistical interaction between the space evoked by the target sentence and the spatial adverbial position.

\section{Method}

\section{Participants}

Forty-two students of the University of Provence participated in the experiment. All participants were native French speakers. 


\section{Materials}

The materials consisted of 45 narratives, 24 of which were used as experimental items, and 21 of which were used as filler items. The experimental texts were constructed according to the following diagram: The first sentence introduced an overall space (OvSp) specified by an argument prepositional phrase (in a hotel in example 2). The second sentence introduced the Origin Space (OrSp), which is also an argument PP (to her room in 2). The OrSp referred to the place from where the character perceives the following described scenes (the window's room in 2). Both of the following sentences referred to events that took place in a space that we called Space 1 (Sp1) denoted by a first adverbial (In the park in 2). Once again, two sentences referred to events that took place in a new space $(\mathrm{Sp} 2)$ denoted by a second locating adverbial (In front of the entrance in 2). Then, there was the target sentence referring to an event taking place in one of the three previous spaces. The subject of the target sentence was a definite NP referring to a specific entity which was associated specifically either to OrSp (the bed in 2), or to $\mathrm{Sp} 1$ (the lanes in 2), or to $\mathrm{Sp} 2$ (the front steps in 2). This definite anaphoric NP was linked to a prototypical part of one of these spaces and thus forced the participants to retrieve this particular space in their situation model.

Each experimental text had two versions. In one version, the adverbial expressions referring to Space 1 and Space 2 were detached at the beginning of the sentences (preposed condition as in $2 \mathrm{a}$ ). In the other version, the same adverbial expressions were non-detached at the end of the sentences (postposed condition as in $2 b$ ).

The filler texts were of comparable lengths to the experimental texts and were used to obscure manipulation. To make sure that participants paid attention to the texts they were reading, they were presented with a simple comprehension question after each text, with half of the comprehension questions requiring a "right" response and the other half requiring a "wrong" response. 


\section{Design and Procedure}

The experimental session began with four practice texts, and then the 24 experimental texts intermixed with all 21 filler texts. Each experimental text could be presented in six versions, defined by crossing two experimental factors, namely the position of the spatial adverbial (sentence-initial or sentence-final) and the space evoked by the target sentence (OrSp or Sp1 or $\mathrm{Sp} 2)$. The 48 participants were assigned to six groups so that a participant never read more than one of the six versions of each text.

The texts were presented sentence after sentence, self-paced by the participants, who were instructed to press the space bar to trigger the display of a new sentence. On doing this, the display of the current sentence was immediately replaced by the display of the following sentence and so on. Pressing the space bar after reading the final sentence of a text elicited the presentation of the comprehension question (e.g., Mary had a room in a hotel. RIGHT/WRONG?). Participants responded to the question by pressing the appropriate key. The sentences were shown on a single line in normal uppercase and lowercase letters. The presentation of the texts was randomized. The experimental session lasted approximately 20 $\min$.

\section{Results}

Reading times for the target sentences were analysed in two analyses of variance (ANOVAs), one treating subjects as a random factor $(\mathrm{F} 1)$ and one treating items as a random factor $(\mathrm{F} 2)$. In both analyses, the position of the spatial adverbial and the space evoked by the target sentence were within factors. In the first analysis, participant group was a between factor. In the second analysis, item group was a between factor. 
Because there was no evidence for effects of our manipulations in other sentences, and because fully analysing other sentences does not test any hypothesis-relevant predictions, reading times were fully analysed only for the target sentences. The mean reading times for the target sentences are presented in Table I. The analyses of variance showed no main effects of the position of the spatial adverbial (both $F s<1$ ), nor of the space evoked by the target sentence (both Fs<1). The interaction between the two variables was significant for the participant analysis but not for the item analysis $(\mathrm{F} 1(2,72)=3.16, \mathrm{p}<.05 ; \mathrm{F} 2<1)$. The target sentence the more easily processed was not the same depending on whether the spatial adverbials were in sentence-initial or sentence-final position. In the preposed condition, shorter reading times for the target sentence were observed when it referred to an event that took place in the first spatial frame (Sp1). In the postposed condition, shorter reading times for the target sentence were observed when it referred to an event that took place in the last space mentioned (Sp2).

Table I. Results of Experiment 1A: Mean reading times (in ms) on the target sentence as a function of the adverbial position and of the space evoked

\begin{tabular}{|l|l|l|l|}
\hline & OrSp & Sp1 & Sp2 \\
\hline Sentence-initial & 1625.73 & 1502.42 & 1576.46 \\
\hline Sentence-final & 1576.46 & 1555.12 & 1522.65 \\
\hline
\end{tabular}

These results confirmed that spatial adverbials don't play the same role depending on whether they are in sentence-initial or in sentence-final position. However, contrary to our predictions, it was the first spatial frame introduced (Sp1) that was the most accessible when adverbials were in sentence-initial position. In order to confirm this unexpected finding, we decided to replicate the experiment with several slight modifications in the materials: the number of filler texts was increased and the experimental texts were more systematically controlled. 


\section{Experiment 1B}

\section{Method}

\section{Participants}

Twenty-four students of the University of Paris 3 participated in the experiment. All participants were native French speakers.

\section{Materials}

The materials consisted of 62 narrative texts, 24 of which were used as experimental items, and 38 of which were used as filler items. In Experiment 1A, the PPs referring to Sp1 and Sp2 referred either to subparts of the Overall Space (like in the sample text in 2) or to independent places. In Experiment 1B, all the PPs referring to $\mathrm{Sp} 1$ and $\mathrm{Sp} 2$ mention places visually accessible from the Origin Space but which are not a subpart of the Overall Space. Furthermore, in Experiment 1A, several sentences included in spaces 1 and 2 referred to events inaccessible to eyesight such as Birds were singing. These sentences were systematically removed. A sample of texts used in Experiment 1B is given in (5a-b).

(5a) Marie logeait dans un hôtel.(S0) Elle monta dans sa chambre (S1) et regarda par la fenêtre.(S2) Sur les parkings des grands magasins, quelques voitures cherchaient une place.(S3) Des employés poussaient des files de caddies.(S4) Près du terrain de foot, des jeunes se chamaillaient.(S5) Un couple se promenait.(S6)

(Target) Les rideaux s'envolaient dans le courant d'air.(S7)/ Les enseignes lumineuses étaient allumées.(S7)/ La pelouse étaient éclairée.(S7)

Le printemps approchait.(S8) 
Mary was staying in a hotel.(SO) She went up to her room ${ }_{(S 1)}$ and looked out the window.(S2) In the car parks of the department stores, some cars were looking for a parking place. ${ }_{(S 3)}$ Some employees were wheeling trolleys. (S4) Near the football field, some kids were bickering.(S5) A couple was walking.(S6)

(Target) The curtains were blown in the draught.(S7) The neon signs were lit.(S7) The lawn was lit.(S7)

Spring was coming.(S8)

(5b) Marie logeait dans un hôtel.(s0) Elle monta dans sa chambre (s1) et regarda par la fenêtre.(S2) Quelques voitures cherchaient une place sur les parkings des grands magasins.(\$3) Des employés poussaient des files de caddies.(\$4) Des jeunes se chamaillaient près du terrain de foot.(S5) Un couple se promenait.(S6)

(Target) Les rideaux s'envolaient dans le courant d'air.(S7)/ Les enseignes lumineuses étaient allumées.(S7)/ La pelouse étaient éclairée.(S7)

Le printemps approchait.(S8)

Mary was staying in a hotel.(SO) She went up to her room (S1) and looked out the window.(S2) Some cars were looking for a parking place in the car parks of the department stores. (S3) Some employees were wheeling trolleys. (S4) Some kids were bickering near the football field.(S5) A couple was walking.(S6)

(Target) The curtains were blown in the draught.(S7) The neon signs were lit.(S7) The lawn was lit.(S7)

Spring was coming.(S8)

\section{Design and Procedure}

The design and procedure were the same as in Experiment 1A. The experimental session lasted approximately $30 \mathrm{~min}$. 


\section{Results}

Analyses were performed as in Experiment 1A. The mean reading times before the target sentence can be found in Table II. The mean reading times on the target sentence (S7) and on the last sentence (S8) are presented in Table III. The main results of Experiment 1A were replicated. The analyses of variance showed no main effects of the position of the spatial adverbial (both Fs $<1)$, nor of the space evoked by the target sentence $(F 1(2,36)=1.28, p>.10$; $\mathrm{F} 2<1)$. The interaction between the two variables was significant $(\mathrm{F} 1(2,36)=4.28, \mathrm{p}<.025$; $\mathrm{F} 2(2,46)=3.24, \mathrm{p}<.05)$. Pairwise comparisons confirmed the nature of this interaction: When the target sentence evoked the Origin Space or Space 2, there was no significant effect of the position (respectively, $\mathrm{F} 1(1,18)=1.46, \mathrm{p}>.10 ; \mathrm{F} 2(1,23)=1.19, \mathrm{p}>.10$ and $\mathrm{F} 1(1,18)=3.37$, $\mathrm{p}=.079 ; \mathrm{F} 2(1,23)=1.58, \mathrm{p}>.10)$. On the other hand, when the target sentences evoked Space 1, there was an effect of the position, marginally significant by subject and significant by item, such that reading times in the sentence-initial position condition were significantly shorter than in the postposed condition $(F 1(1,18)=3.54, p=.073 ; F 2(1,23)=10.02, p<.005)$. Simple effects tests, in the sentence-initial position condition, revealed a significant effect of the space evoked by the target sentence $(\mathrm{F} 1(2,36)=3.24, \mathrm{p}<.05 ; \mathrm{F} 2(2,46)=2.32, \mathrm{p}=.10)$ and no reliable effect in the postposed condition (both Fs $<1$ ).

Table II. Results of Experiment 1B: Mean reading times (in ms) sentence by sentence as a function of the adverbial position

\begin{tabular}{|c|c|c|c|c|c|c|}
\hline & S1 & S2 & S3 & S4 & S5 & S6 \\
\hline $\begin{array}{l}\text { Sentence- } \\
\text { initial }\end{array}$ & 4459.84 & 3267.47 & 2601.05 & 2069.69 & 2783.45 & 1989.50 \\
\hline $\begin{array}{c}\text { Sentence- } \\
\text { final }\end{array}$ & 4040.98 & 3459.69 & 2706.47 & 2203.42 & 2726.95 & 2031.81 \\
\hline
\end{tabular}


Table III. Results of Experiment 1B: Mean reading times (in ms) on the target and the last sentences as a function of the adverbial position and of the space evoked

\begin{tabular}{|c|l|l|l|l|l|l|}
\hline & \multicolumn{4}{|l|}{ Target sentence } & \multicolumn{2}{l|}{ Last sentence } \\
\hline & OrSp & Sp1 & Sp2 & OrSp & Sp1 & Sp2 \\
\hline $\begin{array}{c}\text { Sentence- } \\
\text { initial }\end{array}$ & 2016.57 & 1692.32 & 2019.66 & 1580.33 & 1702.46 & 1759.43 \\
\hline $\begin{array}{c}\text { Sentence- } \\
\text { final }\end{array}$ & 1891.93 & 1893.24 & 1803.67 & 1661.96 & 1486.74 & 1624.8 \\
\hline
\end{tabular}

The results confirmed that the position of spatial adverbials influence the on-line text comprehension. As in Experiment 1A, Space 1 was the most accessible space in the preposed condition.

\section{Discussion}

As we have said, our previous expectations were that in Experiments $1 \mathrm{~A}$ and $1 \mathrm{~B}$, in the preposed condition, participants would have more difficulties processing the target sentences referring to Space 1 than to Space 2. In other words, we made the hypothesis (illustrated in Figure 2) that in the preposed condition, the target sentence (S7), containing the subject definite anaphoric NP, would be read faster when its subject definite NP referred to an entity associated to $\mathrm{Sp} 2$, than when it referred to $\mathrm{Sp} 1$ which was closed by $\mathrm{Sp} 2$ (according to the Right Frontier Constraint).

\begin{tabular}{ll|l} 
OvSp & OrSp & Sp1 \\
S0. & S1 et S2. & $\operatorname{Adv}_{1}$, S3. S4.
\end{tabular}$\quad$\begin{tabular}{l} 
Sp2 \\
\cline { 2 - 2 } 2, S5. S6.
\end{tabular}

Figure 2. Expectations for Experiments 1A and 1B. 
Contrary to our expectations, the results of Experiments $1 \mathrm{~A}$ and $1 \mathrm{~B}$ showed that, in the preposed condition, the target sentence was processed more easily when it referred to Sp1 as illustrated in Figure 3.

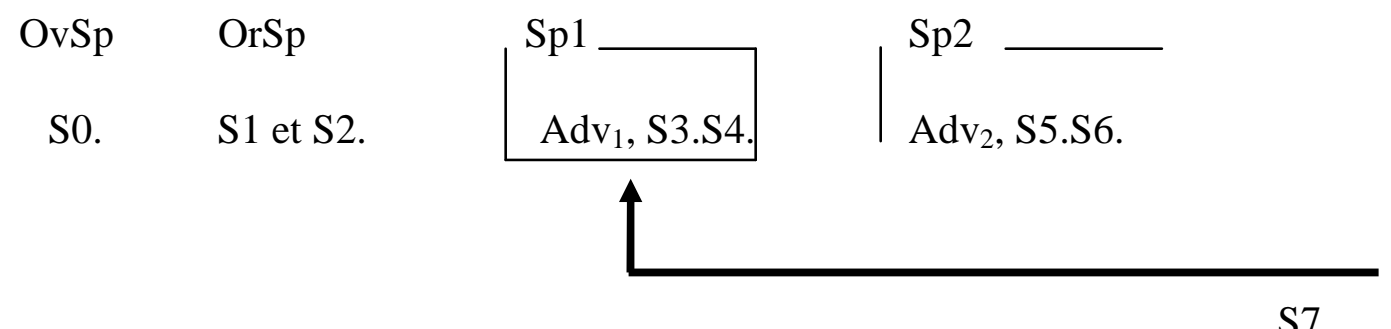

Figure 3. Schematic representation of the results in Experiments $1 \mathrm{~A}$ and 1B.

These first results show that the preposing of adverbials does induce an effect different from a recency effect: if we had observed an advantage for the target sentence referring to Sp2, this facilitation could have been attributed to a recency effect. But, we observed an advantage for the target sentence evoking Sp1. This advantage for Sp1 in the preposed condition clearly indicates that preposed and postposed spatial adverbials are not processed in the same way. In order to examine the factors that could account for the high accessibility of Sp1, we conducted two new experiments (Experiments 2 and 3 described below).

\section{EXPERIMENT 2}

The aim of Experiment 2 was to test a factor that could explain that Sp2 was less accessible than Sp1. In Experiments 1A and 1B, the first and second spatial framing adverbials included two sentences each and thus appeared as symmetrical. Consequently, the second spatial frame (Sp2) would seem as closed as the first one (Sp1). Making the assumption that both $\mathrm{Sp} 1$ and 
Sp2 were closed, the readers would infer that the event evoked by the target sentence should take place in $\mathrm{Sp} 1$ rather than in $\mathrm{Sp} 2$.

In this experiment, we removed the second sentence included in Sp2 (S6 in the sample text in

5) in order to eliminate the symmetry between $\mathrm{Sp} 1$ and $\mathrm{Sp} 2$. In this way, we expect to facilitate the interpretation of the target sentence in Sp2: reading times, in the preposed condition, should be shorter when the target sentence evoked Sp2.

\section{Method}

\section{Participants}

Twenty-four students of the University of Paris 3 participated in the experiment. All participants were native French speakers. None of them participated in Experiment 1B.

\section{Materials, Design and Procedure}

The materials were identical to the materials of Experiment 1B except that second sentence in Sp2 was removed (A couple was walking in the sample text in 5). The design and procedure were the same as in Experiment 1B.

\section{Results}

Analyses were performed as in the previous two experiments. The mean reading times before the target sentence can be found in Table IV. The mean reading times on the target sentence and on the last sentence are presented in Table V. The analyses of variance showed no main effects of the position of the spatial adverbial (both Fs<1), nor of the space evoked by the target sentence (both Fs<1). The interaction between the two variables was significant $(\mathrm{F} 1(2,36)=5.57, \mathrm{p}<.01 ; \mathrm{F} 2(2,46)=2.83, \mathrm{p}=.067)$ but the pattern was different to the previous experiments. Reading times were shorter when the target sentences evoked Space 2 in the 
preposed condition than in the postposed condition. Pairwise comparisons revealed that this effect was significant in the subject analysis but not in the item analysis $(F 1(1,18)=7.43$, $\mathrm{p}<.05 ; \mathrm{F} 2(1,23)=2.74, \mathrm{p}>.10)$. Whereas there was no longer a significant difference for the target sentences evoking Space 1 in preposed versus postposed conditions (both Fs $<1$ ). In this experiment, the longer reading times for the target sentences evoking the Origin Space in the preposed condition (also observed in previous experiments), did reach significance in the subject analysis but not in the item analysis $(\mathrm{F} 1(1,18)=4.98, \mathrm{p}<.05 ; \mathrm{F} 2(1,23)=2.93, \mathrm{p}=.09)$. Simple effects tests revealed a significant effect of the space evoked by the target sentence in the preposed condition in the subject analysis but not in the item analysis $(\mathrm{F} 1(2,36)=3.91$, $\mathrm{p}<.05 ; \mathrm{F} 2(2,46)=1.31, \mathrm{p}>.10)$ and no reliable effect in the postposed condition (both Fs $<1)$. We conducted a combined analysis of the data from Experiment 1B and Experiment 2 for the target sentences evoking Space 2. Experiment was treated as a between-subject and a withinitem variable. The analysis produced a significant interaction Position of the spatial frame $\times$ Experiment $(\mathrm{F} 1(1,36)=8.47, \mathrm{p}<.01 ; \mathrm{F} 2(1,23)=4.45, \mathrm{p}<.05)$. Whereas in Experiment $1 \mathrm{~B}, \mathrm{Sp} 2$ was more accessible in the postposed condition, in Experiment 2, it becomes more accessible in the preposed condition. This decrease of the reading times when the target sentence evoked Space 2 in the preposed condition suggests that readers are sensitive to the symmetry between Space 1 and Space 2.

Table IV. Results of Experiment 2: Mean reading times (in ms) sentence by sentence as the function of the adverbial position

\begin{tabular}{|c|c|c|c|c|c|}
\hline & S1 & S2 & S3 & S4 & S5 \\
\hline $\begin{array}{l}\text { Sentence- } \\
\text { initial }\end{array}$ & 4849.76 & 3817.97 & 3186.54 & 2673.4 & 3290.72 \\
\hline $\begin{array}{c}\text { Sentence- } \\
\text { final }\end{array}$ & 4824.95 & 4198.61 & 3286.98 & 2542.39 & 3321.34 \\
\hline
\end{tabular}


Table V. Results of Experiment 2: Mean reading times (in ms) on the target and the last sentences as a function of the adverbial position and of the space evoked

\begin{tabular}{|c|l|l|l|l|l|l|}
\hline & \multicolumn{4}{|l|}{ Target sentence } & \multicolumn{2}{l|}{ Last sentence } \\
\hline & OrSp & Sp1 & Sp2 & OrSp & Sp1 & Sp2 \\
\hline $\begin{array}{c}\text { Sentence- } \\
\text { initial }\end{array}$ & 2242.88 & 2042.91 & 2034.04 & 1659.5 & 1615.11 & 1666.93 \\
\hline $\begin{array}{c}\text { Sentence- } \\
\text { final }\end{array}$ & 2057.27 & 2131.03 & 2207.21 & 1623.63 & 1685.3 & 1618.48 \\
\hline
\end{tabular}

\section{Discussion}

The results of Experiment 2 are schematised in Figure 4. We may recall that, in Experiments 1A and 1B, the spatial PPs appeared in S3 and S5 and the subjects of these two sentences, like those of S4 and S6, were indefinite NPs. Because the verbs in all these sentences were also in the same tense (imparfait), and that S3, S4, S5 and S6 were constructed along a same syntactic pattern, it seems likely that these formal similarities focus on the symmetry of S3-S4 and S5-S6 in the preposed condition where S3 and S5 begin by a PP of the same semantic category. In Experiment 2, this symmetry no longer existed because the sentence S5 containing the second spatial PP was not followed by another sentence before the target sentence. The fact that in this experiment the reading times of the target sentences corresponding to $\mathrm{Sp} 2$ were shorter in the preposed condition than in the postposed condition suggested that readers were sensitive to the structural symmetry of the two spatial frames, Sp1 and $\mathrm{Sp} 2$, in Experiments $1 \mathrm{~A}$ and 1B. These results confirm that the preposing of spatial PPs contributed to the structuring of information, as predicted by the framing hypothesis. 


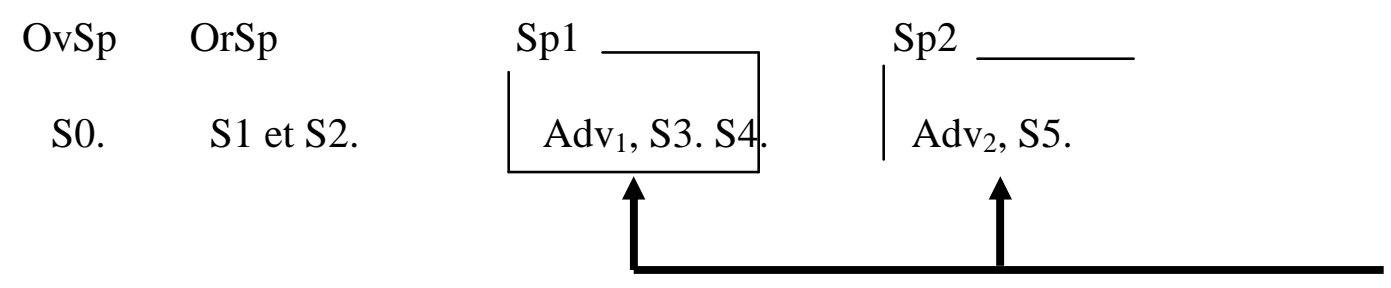

Figure 4. Schematic representation of results of Experiment 2.

\section{EXPERIMENT 3}

The aim of Experiment 3 was to test a factor explaining that the Origin Space (OrSp) was less accessible than Sp1. In Experiments 1A and 1B, the PP referring to the Origin Space (dans sa chamber / in her room in the sample text in 5) was not an adverbial but a locative argument of the verb (elle monta dans sa chambre / she went up to her room) and so, was not (and could not be) detached in a sentence-initial and potentially framing position. The PP referring to Sp1 was the first in a framing position. This framing position could explain why readers infer that the target sentence should take place in Sp1 rather than in the Origin Space.

In Experiment 3, the PP introducing the Origin Space was no longer an argument of the verb as in the previous experiments but it was an adverbial. Its adverbial status allowed to detach it in a sentence-initial and potentially framing position. In sentence-initial position, it would open a spatial frame (that we called Space 0) and therefore have the same status as the adverbials introducing Sp1 and Sp2. In this way, we expect to facilitate the interpretation of the target sentence in Space $0(\mathrm{Sp} 0)$. 


\section{Method}

\section{Participants}

Twenty-four students of the University of Paris 3 participated in the experiment. All participants were native French speakers. None of them participated in the previous experiments.

\section{Materials, Design and Procedure}

The materials were derived from those used in Experiments $1 \mathrm{~B}$ by introducing the Origin Space by a spatial adverbial. A sample of text used in Experiment 3 is given in (6a-b). The design and procedure were the same as in previous experiments.

(6a) Marie logeait dans un hôtel.(s0) Dans sa chambre, elle resta songeuse un moment (S1) et regarda par la fenêtre.(S2) Sur les parkings des grands magasins, quelques voitures cherchaient une place.(S3) Des employés poussaient des files de caddies.(S4) Près du terrain de foot, des jeunes se chamaillaient.(S5) Un couple se promenait.(S6)

(Target) Les rideaux s'envolaient dans le courant d'air.(S7)/ Les enseignes lumineuses étaient allumées.(S7)/ La pelouse étaient éclairée.(S7)

Le printemps approchait.(S8)

Mary was staying in a hotel.(SO) In her room, she remained thoughtful for a moment ${ }_{(S I)}$ and looked out the window.(S2) In the car parks of the department stores, some cars were looking for a parking place. (S3) Some employees were wheeling trolleys. (S4) Near the football field, some kids were bickering.(S5) A couple was walking.(S6)

(Target) The curtains were blown in the draught.(S7) The neon signs were lit.(S7) The lawn was lit.(S7)

Spring was coming.(S8) 
(5b) Marie logeait dans un hôtel.(S0) Elle resta songeuse un moment dans sa chambre ${ }_{(\mathrm{S} 1)}$ et regarda par la fenêtre.(S2) Quelques voitures cherchaient une place sur les parkings des grands magasins.(S3) Des employés poussaient des files de caddies.(S4) Des jeunes se chamaillaient près du terrain de foot.(S5) Un couple se promenait.(S6)

(Target) Les rideaux s'envolaient dans le courant d'air.(S7)/ Les enseignes lumineuses étaient allumées.(S7)/ La pelouse étaient éclairée.(S7)

Le printemps approchait.(S8)

Mary was staying in a hotel.(SO) She remained thoughtful for a moment in her room ${ }_{(S I)}$ and looked out the window.(S2) Some cars were looking for a parking place in the car parks of the department stores. (S3) Some employees were wheeling trolleys. (S4) Some kids were bickering near the football field.(S5) A couple was walking.(S6)

(Target) The curtains were blown in the draught.(S7) The neon signs were lit.(S7) The lawn was lit.(S7)

Spring was coming.(S8)

\section{Results}

Analyses were performed as in previous experiments. The mean reading times before the target sentence can be found in Table VI. The mean reading times on the target sentence (S7) and on the last sentence (S8) are presented in Table IV. The analyses of variance showed no main effects of the position of the spatial adverbial (both Fs $<1$ ), nor of the space evoked by the target sentence (both $\mathrm{Fs}<1$ ). The interaction between the two variables was no more significant (both Fs<1). Pairwise comparisons, in the preposed condition, revealed no significant effect when the target sentences corresponded to Space 1 (both Fs<1), nor when the target sentences corresponded to Space 2 (both Fs $<1$ ). The analysis combining Experiment 1B and Experiment 3, when the target sentences evoked Space 1, revealed an 
interaction Position of the spatial frame $\times$ Experiment marginally significant by subject and significant by item $(\mathrm{F} 1(1,36)=2.74, \mathrm{p}=.10 ; \mathrm{F} 2(1,23)=4.61, \mathrm{p}<.05)$. This interaction suggests that the advantage for Space 1 observed in Experiment 1B disappears when the Origin Space is in a framing position. The interaction Position $\times$ Experiment was not significant when the target sentences evoked Space $2(\mathrm{~F} 1(1,36)=1.76, \mathrm{p}>.10 ; \mathrm{F} 2<1)$, nor when the target sentences evoked the Origin Space $(F 1(1,36)=1.2, \mathrm{p}>.10 ; \mathrm{F} 2(1,23)=1.86, \mathrm{p}>.10)$.

Table VI. Results of Experiment 3: Mean reading times (in ms) sentence by sentence as the function of the adverbial position

\begin{tabular}{|c|c|c|c|c|c|c|}
\hline & S1 & S2 & S3 & S4 & S5 & S6 \\
\hline $\begin{array}{l}\text { Sentence- } \\
\text { initial }\end{array}$ & 4447.82 & 4172.45 & 3015.29 & 2435.84 & 3183.21 & 2337.49 \\
\hline $\begin{array}{c}\text { Sentence- } \\
\text { final }\end{array}$ & 4175.85 & 3806.70 & 3072.79 & 2409.11 & 3152.41 & 2223.8 \\
\hline
\end{tabular}

Table VII. Results of Experiment 3: Mean reading times (in ms) on the target and the last sentences as a function of the adverbial position and of the space evoked

\begin{tabular}{|c|l|l|l|l|l|l|}
\hline & \multicolumn{4}{|l|}{ Target sentence } & \multicolumn{2}{l|}{ Last sentence } \\
\hline & OrSp & Sp1 & Sp2 & OrSp & Sp1 & Sp2 \\
\hline $\begin{array}{c}\text { Sentence- } \\
\text { initial }\end{array}$ & 2141.1 & 1996.53 & 2027.14 & 1580.33 & 1702.46 & 1759.43 \\
\hline $\begin{array}{c}\text { Sentence- } \\
\text { final }\end{array}$ & 2101.99 & 1972.07 & 2039.94 & 1661.96 & 1486.74 & 1624.8 \\
\hline
\end{tabular}

\section{Discussion}

Experiment 3 was conducted in order to provide an explanation to the fact that, in Experiments 1A, 1B and 2, readers do not go back to the OrSp. Experiment 3 is based on the same materials as Experiment 1B, except that the Origin Space denoted by the action accomplished by the character (she went up to her room) became an adverbial which could be 
preposed or postposed (In her room, she remained thoughtful for a moment / She remained thoughtful for a moment in her room). With this modification, we expected that the advantage for Sp1, observed in Experiments 1A and 1B in the preposed condition, would turn into an advantage for $\mathrm{Sp} 0$ as illustrated in Figure 5.

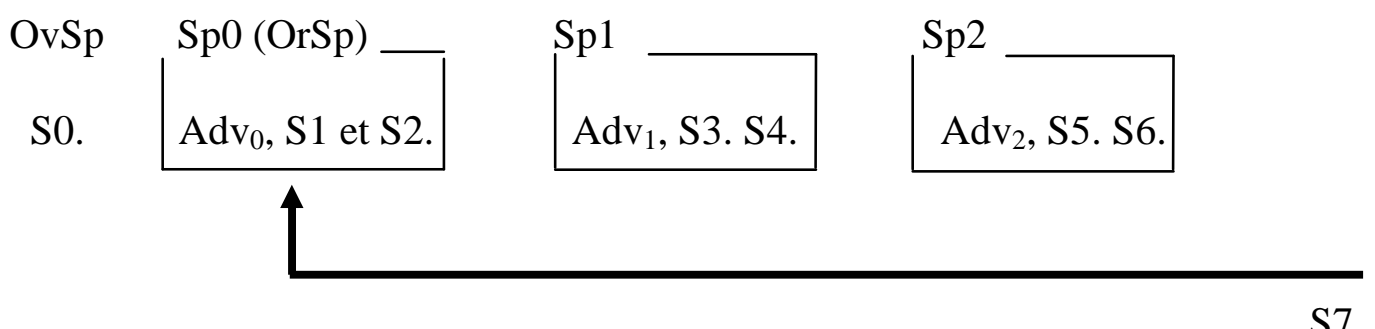

Figure 5. Expectations for Experiment 3.

Contrary to this expectation the results were not significant, suggesting that the three interpretations were also likely, as illustrated in Figure 6. We shall explain these results in the general discussion.

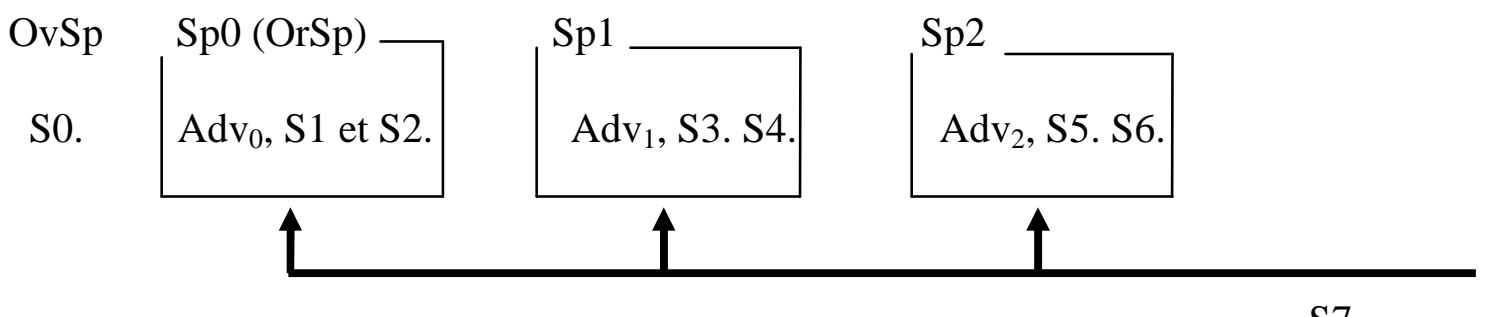

Figure 6. Schematic representation of the results of Experiment 3.

\section{GENERAL DISCUSSION}

The experimental texts we built and the procedure we adopted in the series of experiments reported above were expressly designed to explore the possible cohesive function of preposed 
adverbials. Concerning the forward-looking cohesive potential of preposed adverbials, our hypothesis was that preposed spatial PPs could integrate, in a same spatial frame, situations occurring in the same place. In order to facilitate reading, a translated sample of text is reprinted below.

Mary was staying in a hotel.so She went up to her room s1 and looked out the window.s2 In the car parks of the department stores, some cars were looking for a

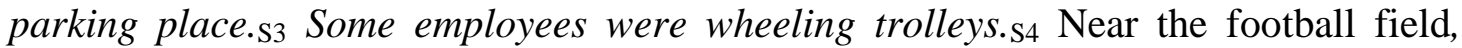
some kids were bickering. ${ }_{\mathrm{s} 5}$ A couple was walking.s6

The curtains were blown in the draught.s7

The neon signs were lit.s7

The lawn was lit.s7

Spring was coming. $\mathrm{s} 8$

The fact that in Experiments 1A and 1B the participants preferred to tie the target sentences to $\mathrm{Sp} 1$ rather than to $\mathrm{Sp} 2$ only when spatial adverbials were preposed, shows that readers distinguished the two frames opened by these adverbials. Our data are broadly in line with Bestgen and Vonk's (2000) results reported above. Only the preposed spatial PPs function as markers of integration. They open a frame designed to integrate the incoming information. We have seen in Experiments 1A and 1B that readers expected the text to continue on Sp1 rather than on $\mathrm{Sp} 2$.

Our results indicate that the preposing of spatial adverbials functions as a linguistic cue foregrounding the readers' attention on the place where situations occur, as provided in Zwaan's Event Indexing Model (Zwaan, Langston \& Graesser, 1995; Zwaan, Magliano \& Graesser, 1995). Secondly, as we have seen, the Right Frontier Constraint cannot explain the preference for Sp1 observed in Experiments 1A and 1B. But these results can be explained as illustrated in Figure 7. In the preposed spatial adverbial condition, the readers: 
- Closed Sp2 after reading S6;

- Updated their mental model and integrated Sp1 and Sp2 in a super-ordinate informational structure, and hence created a frontier after the OrSp;

- Tied the target sentence S7 to the upper node of this super-ordinate informational structure and then to the first subordinate accessible node, namely Sp1.

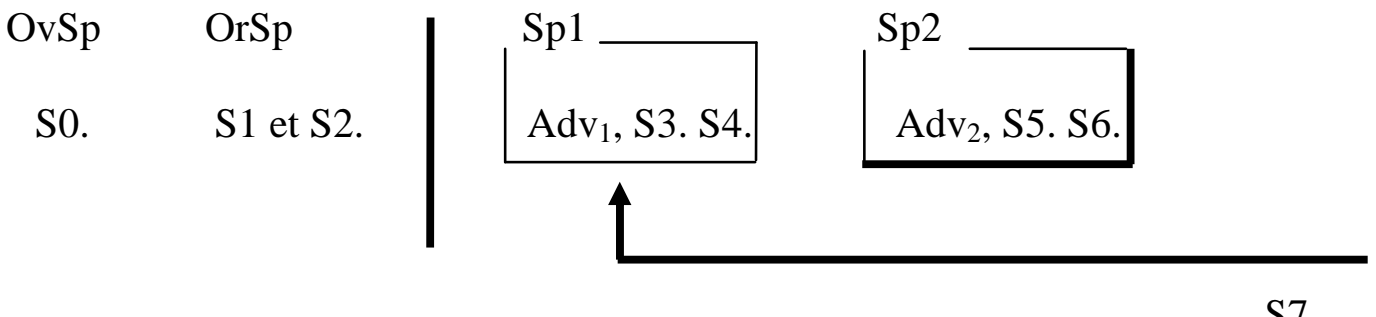

Figure 7. Schematic representation of the interpretative process in Experiments 1A and 1B.

As we have seen in Experiment 3, the transformation of OrSp in a potentially framing spatial adverbial is clearly not sufficient to produce the expected preference for Sp0. How can we explain this result? It may be due to the fact that, in this last experiment, the sentences $\mathrm{S} 1$ and S2 remain different from S3-S4 and S5-S6. We believe that these differences would explain the absence of the expected effect. As can be seen in the sample text in (6), in the preposed condition reproduced below, S1 and S2 are coordinated by et / and and they have a pronominal (elle/she) or elliptic subject which refers to the main character.

Mary was staying in a hotel.so In her room, she remained thoughtful for a moment $\mathrm{s} 1$ and looked out the window.s2 In the car parks of the department stores, some cars were looking for a parking place.s3 Some employees were wheeling trolleys.s4 Near the football field, some kids were bickering. ${ }_{\mathrm{s} 5}$ A couple was walking.s6

The curtains were blown in the draught.s7

The neon signs were lit.s7 
The lawn was lit.s7

Spring was coming. 88

On the contrary, S3, S4, S5 and S6 are juxtaposed and their subjects are indefinite NPs introducing new referents. In S1 and S2, verbs are in "passé simple" (preterit) not in "imparfait" (progressive) as in S3, S4, S5 and S6. The syntactic and semantic characteristics that are common to sentences belonging to $\mathrm{Sp} 1$ and to $\mathrm{Sp} 2$ are not satisfied in $\mathrm{S} 1$ and $\mathrm{S} 2$. The effect of formal symmetry possibly favouring the attachment of the target sentence to $\mathrm{Sp} 0$ cannot function. Moreover, S1 and S2 refer to volitional processes, ordered chronologically. $\mathrm{S} 1$ and S2 are linked by a narration relation, contrary to the situations denoted by S3-S4 and S5-S6, which are linked by a background relation (in the terminology of Segmented Discourse Representation Theory). But the most important linguistic cue is that S1 and S2 report actions which are immediately associated to a motivation of the character (the character looked out the window in order to see what happens outside). Such goal inferences play a crucial role in the interpretation and the updating of situation models. This role has been emphasized by Zwaan and Radvansky (1998) and many other authors, particularly Graesser, Singer and Trabasso (1994) in their constructionist approach. For instance, among the six production rules implementing the reader's active comprehension strategies when reading narrative texts, Graesser, Singer and Trabasso consider, in their model, goal assignation to be the most important strategy and namely that readers "generate super-ordinate goals (i.e. motives) of character actions" (p. 380) as soon as possible. Such a goal assignation probably happens in our texts in which S1 and S2 refer to actions accomplished by a character in order to look at his/her surroundings. The sentences S4, S5, S6 and S7 are interpreted as reported perceptions. Readers attribute their content to the main character, contrary to S1 and S2, which still describe the actions he/she accomplished. The elaboration of a super-ordinate goal index presumably leads, after reading S2 and S3, to the inference of a super-ordinate Intended 
Space (ISp) ${ }^{3}$, as illustrated in Figure 8 . This ISp could be expressed by a more specific anaphoric locative expression such as en bas, au loin, au delà / below, in the distance, beyond, referring to the place the character is looking at.

\section{Goal index}
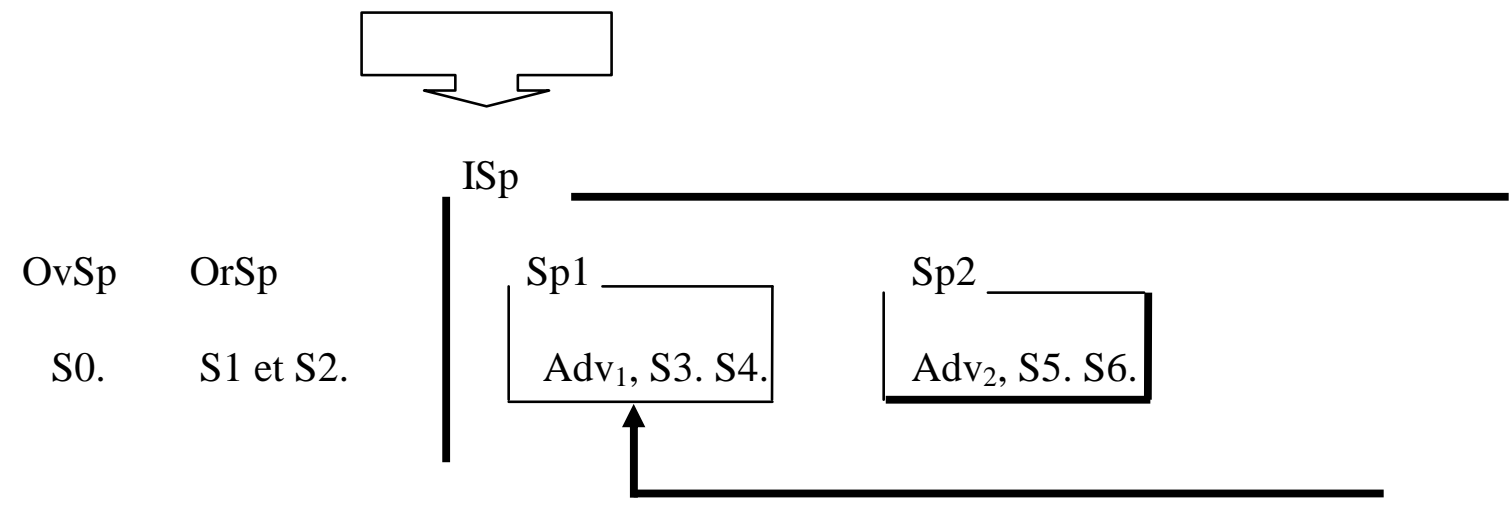

S7

Figure 8. Three right frontiers.

This ISp explains why the frontier between S2 and S3 is strong enough to block the attachment to the OrSp in Experiments 1A, 1B and 2, and even when it is referred to by a preposed potentially framing adverbial as in Experiment 3. Though implicit and subordinate to the goal index, the ISp assumes segmentation and cohesive functions. It opens a frame and introduces the right frontier, explaining the preferred attachment to $\mathrm{Sp} 1$ observed in Experiments $1 \mathrm{~A}$ and $1 \mathrm{~B}$ when the location adverbials were preposed. The ISp frontier remains in Experiment 3. The preposing of the spatial PP in S1 seems to reduce the attractiveness of $\mathrm{Sp} 1$, as is the case in Experiment 2, in which the symmetry between $\mathrm{Sp} 1$ and $\mathrm{Sp} 2$ was suppressed by the deletion of S6.

Overall, the results show that the role of spatial adverbials in text comprehension depends on their position in the host sentence (preposed versus postposed). They confirm the hypothesis

\footnotetext{
${ }^{3}$ Or of a covert spatial stage topic (Erteschik-Schir, 1997, 1999; Lahousse, 2003, 2007).
} 
that the preposing of spatial adverbials is a strong linguistic cue that plays an important role in updating situation models elaborated by readers while they discover narratives such as those we tested. The preposing of spatial adverbials clearly foregrounded the spatial location of the situation denoted by their host sentence. Contrary to postposed ones, preposed spatial adverbials tend to index (i.e. to extend their scope to) the situations denoted by following sentences. Preposed spatial adverbials open frames which are structural units. They function as text organizers.

In the narratives used, a first spatial frame $\mathrm{Sp} 1$ was opened by a first PP and closed by a second spatial PP, which opens a new spatial frame Sp2. In this context, it would have been expected for the target sentence evoking $\mathrm{Sp} 2$ to be read faster than the target sentence evoking Sp1 (because Sp1 was closed by Sp2). Contrary to this expectation, the results showed that the interpretation of the target sentence evoking Sp1 was easier than that of the target sentence evoking Sp2. As indicated above, we assume that this effect is due to a goal index (dominating both spatial frames Sp1 and Sp2), which opens an implicit intended spatial (ISp) frame. This ISp frame introduces a boundary, stronger than the boundaries introduced by the spatial adverbials. Even when the OrSp was introduced by a spatial adverbial, the boundary opened by the goal index remained (as in Experiment 3). These results are well in accordance with Zwaan's Event Indexing Model. Furthermore, they show that the goal indexes play a more important role than the spatial indexes. They also show that, as postulated by linguistics studies (presented in the introduction), preposed spatial adverbials function as markers of text coherence.

\section{References}


Asher, N., Prévost, L., \& Vieu L. (2007). Setting the background in discourse. Discours, 1. Retrieved August 27, 2010, from http://discours.revues.org/index301.html.

Asher, N., \& Lascarides, A. (2003). Logic of Conversation. Cambridge: Cambridge University Press.

Asher, N., 2005. Troubles on the Right Frontier. In M. Aurnague, M. Bras, A. Le Draoulec, \& L. Vieu (Eds.), SEM-05 Proceedings (pp. 3-12), Biarritz, France.

Bestgen, Y., \& Costermans, J. (1994). Time, space and action: Exploring the narrative structure an dits linguistic marking. Discourse Processes, 17, 421-446.

Bestgen, Y., Vonk, W. (2000). Temporal adverbials as segmentation markers in discourse comprehension, Journal of Memory and Language, 42, 74-87.

Charolles, M. (2003). De la topicalité des adverbiaux détachés en tête de phrase. In Charolles M., \& Prévost S. (Eds.), Adverbiaux et topiques, Travaux de Linguistique 47 (pp. 11-51). Louvain-la-Neuve : De Boeck Université.

Charolles, M. (2005). Framing Adverbials and their Role in Discourse Cohesion. In M. Aurnague, M. Bras, A. Le Draoulec, \& L. Vieu (Eds.), SEM-05 Proceedings (pp. 13-30), Biarritz, France.

Charolles M. (2006). Un jour (one day) in narratives. In I. Korzen \& L. Lundquist (Eds.), Comparing Anaphors. Between Sentences, Texts and Languages (pp. 11-26). Copenhagen: Samfundslitteratur Press.

Charolles, M., \& Kleiber G. (Eds.) (1999). Associative Anaphora. Journal of Pragmatics.

Charolles, M., \& Péry-Woodley, M-P. (Eds.) (2005). Les adverbiaux cadratifs. Langue Française, 148.

Charolles, M., \& Prévost S. (Eds.) (2003). Adverbiaux et topiques. Travaux de Linguistique, 47. 
Charolles, M., \& Vigier, D. (2005). Les adverbiaux en position préverbale : portée cadrative et l'organisation des textes. Langue Française, 148, 9-30.

Costermans, J., \& Bestgen, Y. (1991). The role of temporal markers in the segmentation of narrative discourse. European Bulletin of Cognitive Psychology, 11, 349-370.

Crompton, P. (2006). The effect of position on the discourse scope of adverbials. Text and Talk, 26(3), 245-279.

Diessel, H. (2001). The ordering distribution of main and adverbial clauses: A typological study. Language, 77(2), 433-455.

Downing, A. (1991). An alternative approach to theme: A systemic functional perspective. Word, 42(2), 119-143.

Erteschik-Shir, N. (1997). The dynamics of focus structure. Cambridge: CUP.

Erteschik-Shir, N. (1999). Focus structure and scope. In G. Rebuschi \& L. Tuller (Eds.) Grammar of focus (pp. 119-150). Amsterdam/Philadelphia: John Benjamins.

Frazier L., Fodor J. D. (1978). The sausage machine: A new two-stage parsing model. Cognition, 6, 291-325.

Gernsbacher, M.A. (1990). Language comprehension as structure building. Hillsdale, NJ: Erlbaum.

Givon, T. (1995). Functionalism and Grammar. Amsterdam: Benjamins.

Goutsos, D. (1996). A model of sequential relations in expository text. Text, 16(4), 501-533.

Graesser, A. C., Millis, K. K., \& Zwaan, R. A. (1997). Discourse comprehension. Annual Review of Psychology, 48, 163-189.

Graesser, A. C., Singer, M., \& Trabasso, T. (1994). Constructing inferences during narrative text comprehension. Psychological Review, 101, 371-395.

Grice, H.P. (1975). Logic and conversation. In P. Cole \& J. Morgan (Eds.), Speech Acts (pp. 41-58), New York: Academic Press. 
Halliday, M.A.K. (2004). An Introduction to Functional Grammar (2 ${ }^{\text {nd }}$ ed.). London: Arnold.

Hasselgård, H. (1996). Where and When: Positional and Functional Conventions for Sequences of Time and Space Adverbials in Present-Day English (Doctoral dissertation). Oslo: Scandinavian University Press.

Hasselgård H. (2004). Temporal and spatial adjuncts as elements of texture. In D. Banks (Ed.), Text and Texture, Systemic Functional viewpoints on the nature and structure of text. Paris: L'Harmattan.

Hobbs, J.R. (1990). Litterature and Cognition. Menlo Park, CA: CSLI.

Ho-Dac, M. (2007). La position initiale dans l'organisation du discours : une exploration en corpus. Thèse de doctorat, Université de Toulouse le Mirail.

Ho-Dac, M. \& Pery-Woodley, M-P. (2009). A data-driven study of temporal adverbials as discourse segmentation markers, Discours, 4. Retrieved August 27, 2010, from http://discours.revues.org/index5952.html.

Johnson-Laird, P.N. (1983). Mental models: Towards a cognitive science of language, inference, and consciousness. Cambridge, MA: Harvard University Press.

Kehler, A. (2002). Coherence, Reference, and the Theory of Grammar. CSLI Publications.

Kimball, J. (1973). Seven principles of surface structure parsing in natural language. Cognition, 2(1), 15-47.

Kintsch, W. (1992). How readers construct situation models for stories: The role of syntactic cues and causal inferences. In A. E Healy, S. M. Kosslyn, \& R. M. Shiffrin (Eds.), From learning processes to cognitive processes. Essays in honor of William K. Estes (Vol. 2, pp. 261 -278). Hillsdale, NJ: Erlbaum.

Kleiber, G. (2001). L'anaphore associative. Paris: PUF.

Knott, A., \& Sanders, T. (1998). The classification of coherence relations and their linguistic markers: an exploration of two languages. Journal of Pragmatics, 30, 135-175. 
Lahousse, K. (2003). La complexité de la notion de topique et l'inversion du sujet nominal. Travaux de Linguistique, 47, 111-136.

Lahousse, K. (2007). Implicit stage topics. Discours, 1. Retrieved August 27, 2010, from http://discours.revues.org/index117.html.

Le Draoulec, A., \& Péry-Woodley, M.-P. (2003). Time travel in text: temporal framing in narratives and non-narratives. In L. Lagerwerf, W. Spooren \& L. Degand (Eds.), Determination of Information and Tenor in Texts, Proceedings of Multidisciplinary Approaches to Discourse (pp. 267-275). Amsterdam: Stichting Neerlandistiek \& Münster: Nodus Publikationen.

Le Draoulec A., \& Péry-Woodley M-P. (2005). Encadrement temporel et relations de discours. Langue Française, 148, 45-60.

Lowe, I. (1987). Sentence initial elements in English and their discourse function. Occasional Papers in Systemic Linguistics, 2, 5-34.

Lundquist, L. (2009). Adverbiaux initiaux en danois et en français: Langue, Texte, Mentalité. In I. Korzen \& C. Lavinio (Eds.), Lingue, Culture e Testi Istituzionale. Atti del seminario italo-danese (pp. 141-162). Firenze: Franco Cesati Editore.

Mann, W.C., \& Thompson, S. (1986). Relational Propositions in Discourse. Discourse Processes, 9, 57-90.

Mann, W.C., \& Thompson, S. (1988). Rhetorical Structure Theory: Toward a functional theory of text organization. Text, 8(3), 243-281.

Piérard, S., Bestgen, Y. (2006). Validation d'une méthodologie pour l'étude des marqueurs de la segmentation dans un grand corpus de textes. TAL, 47(2), 89-110.

Polanyi, L., \& Scha, R. (1984). A syntactic approach to discourse semantics. In Tenth International Conference on Computational Linguistics, COLING84, 413-419. 
Prideaux, G.D., \& Hogan, J.T. (1993). Markedness as a discourse management device: The role of alternative adverbial clause orders. Word, 44(3), 397-411.

Quirk, R., Greenbaum, S., Leech, G., and Svartvik, J. (1985). A Comprehensive Grammar of the English Language. London: Longman.

Sanders, T.J.M., \& Spooren, W. (2001). Text representation as an interface between language and its users. In T. Sanders, J. Schilperoord, \& W. Spooren (Eds.), Text Representation Linguistic and psycholinguistic aspects (pp. 29-88). Amsterdam: John Benjamins.

Sarda, L., \& Carter-Thomas, S. (2009). Rôle informationnel et textuel des adverbiaux détachés : exemples anglais et français en sur et on. In L. Florea, C. Papahagi, L. Pop \& A. Curea, (Eds), Directions actuelles en linguistique du texte (pp. 311-328). Cluj : Casa Cartii de Stiinta.

Sarda, L. (2005). Les cadres spatiaux dans les résumés de films : caractérisations des types de transitions entre cadres. Langue Française, 148, 61-79.

Schrepfer-André, G. (2006). Les expressions en "selon $X$ " introductrices de cadres de discours énonciatifs et leur portée textuelle. Thèse de Doctorat, Université de Paris III.

Sperber, D., \& Wilson, D. (1986). Relevance. London: Blackwell.

Terran, E. (2002). Le cadrage temporel en français, Thèse de Doctorat, Université de Paris III.

Thompson, S. (1985). Grammar and written discourse: Initial vs. final purpose clause in English. Text, 5(1-2), 55-84.

Thompson, S.A., \& Longacre, R. E. (1985). Adverbial clauses. In T. Shopen (Ed.), Language Typology and Syntactic Description (Vol. 2, pp. 169-205). Cambridge: Cambridge University Press.

van Dijk, T.A. \& Kintsh, W. (1983). Strategies of discourse comprehension, New-York: Academic Press. 
Vieu, L. \& Prévot, L. (2004). Background in SDRT, Workshop SDRT, TALN-04, Fès, April 22.

Vigier, D. (2004). Les groupes prépositionnels en «en $N »$ : de la phrase au discours. Thèse de Doctorat, Université de Paris III.

Vigier, D. (2005). Les adverbiaux praxéologiques détachés en tête de phrase et leur porté: études sur corpus. Verbum, 27(3), 293-312.

Vigier, D. \& Terran, E. (Eds) (2005). Les adverbiaux cadratifs et l'organisation des textes. Verbum, 27(3).

Virtanen, T. (1992). Discourse functions of adverbial placement in English. Abo: Abo Akademi University Press.

Zwaan, R. A., Langston, M. C., \& Graesser, A. C. (1995). The construction of situation models in narrative comprehension: An event-indexing model. Psychological Science, 6, 292-297.

Zwaan, R. A., Magliano, J. P., \& Graesser, A. C. (1995). Dimensions of situation model construction in narrative comprehension. Journal of Experimental Psychology: Learning, Memory, and Cognition, 21, 386-397.

Zwaan, R.A., \& Radvansky, G.A. (1998). Situation models in language comprehension and memory. Psychological Bulletin, 123, 162-185. 